\title{
Specificity of high-rise construction and real estate markets in the regional economy: an analysis of Russian practice (example of St. Petersburg)
}

\author{
Viktoriya Vilken, Olga Kalinina, Alissa Dubgorn*
}

Peter the Great St. Petersburg Polytechnic University, Institute of Industrial management, Economy and Trade, 195251, Polytechnicheskaya, 29, St.Petersburg, Russia

\begin{abstract}
In paper features of the regional markets of construction the commercial and residential real estate on the example of St. Petersburg are defined. The current situation is analysed, the specific features of branch are revealed. The major factors influencing investors making decisions on construction of various types of objects are defined. The main methods of advance of real estate objects are considered.
\end{abstract}

\section{Introduction}

Among the elements of a market economy, a special place is occupied by real estate and construction, which act as means of production and objects of consumption (land, houses, dachas, apartments, garages). Real estate is the basis of personal existence for citizens and serves as a base for economic activity and development of enterprises and organizations of all forms of ownership. In Russia there is an active development of the real estate market and an increasing number of citizens, businesses and organizations are involved in real estate transactions. Real estate is the main subject of discussion in the privatization of state and municipal property, when renting non-residential premises, when buying and selling residential premises.

In turn, construction is one of the key, fund-forming industries that largely determine the pace of development of the economy of the region and the country as a whole, as well as the solution of the most important social and economic tasks.

The level of competition in the North-West region of Russia is very high, and in order to withstand competition, it is necessary to know the market, the strengths and weaknesses of competitors, to be superior in terms of professionalism in the chosen field.

The purpose of this research is to identify the main and specific features that characterize the markets of construction of commercial real estate and residential housing construction, as well as the real estate market in the field of rent in the Russian practice on the example of St. Petersburg.

\footnotetext{
* Corresponding author: alissa.dubgorn@gmail.com
} 


\section{Analysis of real estate market of St. Petersburg}

The commercial real estate market is oligopolistic, the following barriers are established at the entrance to the industry: first of all, state regulation and strict standards that need to be met, the scale economy factor is also important.

The competition between already functioning companies in the market is centered around the struggle for the client. Also, companies compete for areas and construction sites, in terms of price, service levels and additional services provided to customers.

The logic of the differentiation strategy requires that the company puts behind the basis of differentiation such attributes of the product that would distinguish it from the similar product of competing companies. Indeed, there are very few multifunctional structures in the field of office real estate, because the threat of incorrect positioning is very high and the costs for differentiation are also high [1]. Unlike the strategy of cost leadership, implementation of the differentiation strategy does not require the presence of only one leader in the industry in this case there may be several companies that successfully implement the differentiation strategy [2].

The heavy deficit of hotel rooms in St. Petersburg, as well as the declared preferences from the city authorities for developers of the hotel sector, led to an increase in interest in multi-profile facilities that combine hotel and other functions.

According to the forecast for the development of the market for high-quality office real estate, the demand for quality office space will grow by the time the facility is put into operation, with more attention paid by tenants to the availability of services, of which the most significant are: the required number of parking spaces and availability of a hotel in the nearest zone [3-4]. Due to the fact that rental rates in business centers of class "A" are in the highest price segment, the tenants of the business center will be companies for which the image component of their location and the level and scope of services are important [5-6].

Tenants of class "A" office space are most often represented by international companies, large Russian companies and foreign representational offices.

By type of activity, the most represented companies are in the wholesale and retail trade $(21 \%)$, as well as in the services sector $(11.5 \%)$.

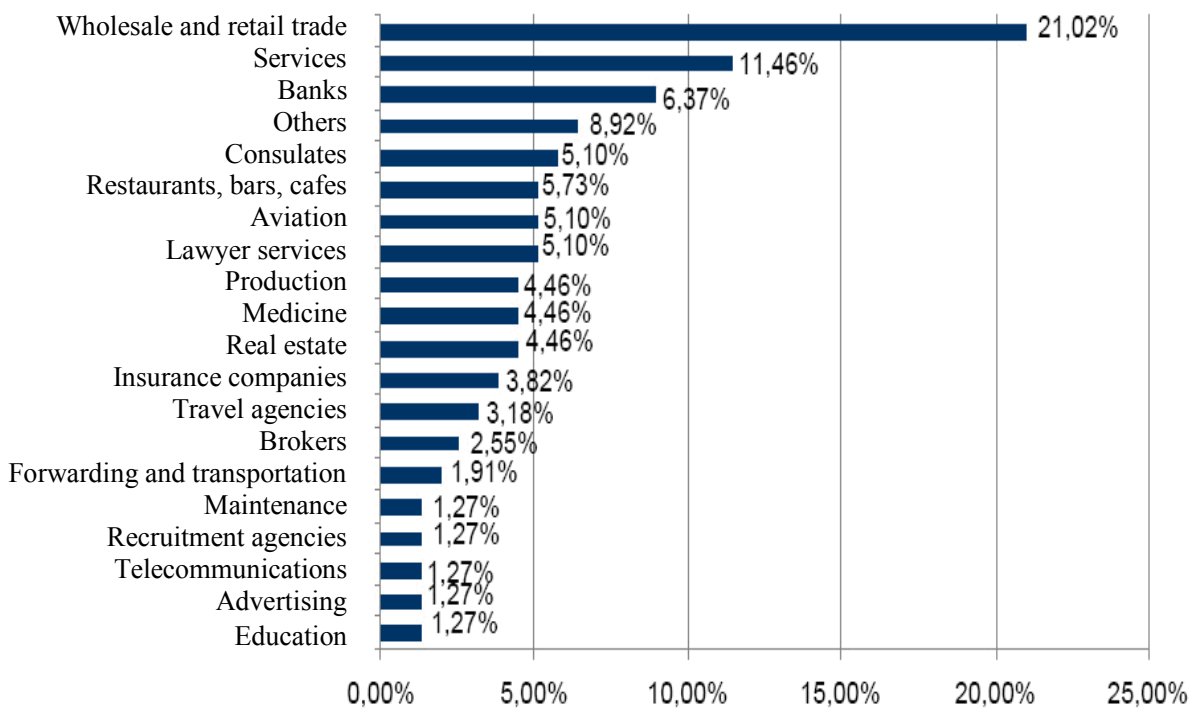

Fig. 1. Distribution of tenants by business lines in St. Petersburg, 2017 
The greatest demand in the market as a whole is for offices with an area of up to 100 square meters, as well as 100-300 square meters. Tenants of such areas are Russian companies and representations of foreign companies. The demand for premises of 300-500 square meters is reduced. High demand is the premises of 501-600 square meters. Tenants are represented by international companies, large Russian companies and foreign representation offices. Annually before the crisis there was an increase in demand for large areas - from 1,000 square meters. Tenants of such areas were financial, insurance, legal, consulting companies. Most likely, this trend will resume after the end of the economic recession. Such companies conclude their contracts for six months or more before the end of the construction of the business center.

Is it expedient to choose the city of St. Petersburg for the implementation of a project? What is the basic information about this segment of the market? According to official statistics, the St. Petersburg economy employs approximately 2,445,200 people. Tenants of business centers are mainly companies working in the field of computer technology, finance, services, real estate, communications.

The share of population employed in these industries is 586200 people, or $24 \%$ of the total number of workers. One employee requires about 7 square meters of office space.

Thus, the market capacity, according to approximate calculations, is 4103400 square meters. With an available supply volume of 1,644,700 square meters, the deficit reaches $2,458,700$ square meters.

According to the company Praktis CB, the provision of Petersburg with high-quality office real estate is 359 square meters for 1 thousand people, which is 8 times less than the similar average in Europe. The average In Europe the average account of office space per person is between 2.5 and 4.5 square meters. In particular, in Warsaw, the availability of business areas is 1 thousand 450 square meters per one thousand citizens, in Paris - 5 thousand 600 square meters, in Stockholm - 5 thousand 700 square meters, in London - 7 thousand 100 square meters. It is also worth noting that in Moscow this indicator is 540 square meters per one thousand citizens. The total market potential in 2017 was 14.6 million square meters. Based on the average European supply of office space, the capacity of the business real estate market in St. Petersburg will be 15.97 million square meters in the next 10-15 years.

Due to the current post-crisis situation, the market for business centers is unstable, but some positive trends are to be noticed.

The volume of input of real estate in first quarter of 2016 was 34.2 thousand square meters, which is comparable to the average value of input in the first quarters of 2009-2014. The commissioning in 2017 amounted to 210-220 thousand square meters, in 2018 this indicator will be about 160-170 thousand square meters.

Dynamic growth of high-quality supply is continuing from 2009 to the present. There is a redistribution of the structure of business centers in the direction of increasing the shares of classes $\mathrm{A}$ and $\mathrm{B}$ and reducing the share of the class $\mathrm{C}$.

At the moment when choosing the class of an object it is necessary to take into account the number of objects being under construction, as well as the number of frozen and suspended objects, the input of which can significantly affect the dynamics of supply and demand in the industry. The number of business centers of class B being under construction is $57 \%$.

LCMC specialists have revealed that for the period from 2010 to 2017 the construction of 24 commercial real estate projects (including shopping complexes, warehouses and hotels) with a total area of 10.8 million square meters was suspended for an indefinite period. Most of them belong to the class B. This means that no matter how high the demand for office space of B class, it will be satisfied at the expense of frozen and suspended objects. 
Accordingly, it can be concluded that the development of investment projects in Class A is purposefully.

In the process of designing a new multifunctional center, it is necessary to solve the problem of the future offices floor-space. Offices should be spacious enough, but not too much so that the tenant does not get the impression that he pays for extra meters.

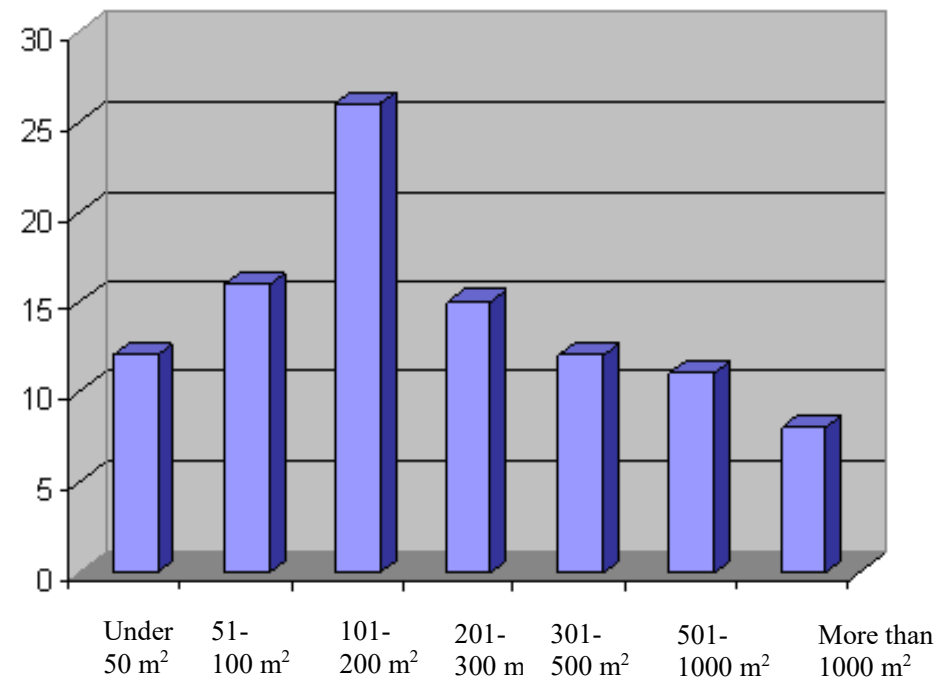

Fig. 2. The structure of demand in the business centers of class A by the size of floor-space in St. Petersburg, 2017

As can be seen from Fig. 2. it is advisable to offer offices from 51 to 300 square meters. In the pre-crisis period, the market had a tendency to increase the demand for offices more than 1000 square meters. Most likely, by the time the objects are completed, this trend will resume.

It is necessary to clearly distinguish the profiling function of the object. Depending on the main purpose of the object, one of the functions is the main one, and the second is the "satellite".

The combination of hotel and office functions is not so common as hotel-shopping. Hospitality is the most complicated function in terms of implementation and management. A fairly successful concept of the facility will help to ensure not only the accommodation (in the hotel) of business travellers working in the office part of the multifunctional center, but also to accommodate numerous non-resident participants of the events carried out in the same center.

Thus, more than half of the declared office space of class "A" are situated in the multifunctional centers.

The infrastructure objects in business centers of class "A" are located primarily on the ground floors. Food facilities can be located on the upper floors. Large infrastructure facilities are located separately from the main building. The class "A" business center usually includes the following infrastructure objects: food facilities (cafes, restaurants); services (small shops, bank office, ATM, currency exchange, laundry, medical center, dry cleaning, travel agency); business infrastructure (conference hall, meeting room, hotel); sports and recreational infrastructure (sauna, fitness center, sports hall, tennis court); entertainment (theater, nightclub, casino, children's entertainment center).

Based on all of the above, we can say about the conclusion about the greater preference on the part of investors for the construction of multifunctional centers. 
This will help to diversify risks to some extent, but at the same time increase investment costs.

Generally, there are two groups of methods for promoting real estate objects:

1. Methods based on the key role of the marketing department.

These methods include placing advertising in the media and other types of advertising media, and then receiving and processing calls from potential customers. This method uses outdoor advertising, print media and, of course, the Internet. In recent years, the Internet has become one of the best means of advertising. One of the most effective ways to promote real estate is contextual advertising on the websites.

2. Methods based on the key role of the brokerage department.

The active methods of attracting tenants include: contacts on the client base, personal connections. The effectiveness of the promotion method increases, if it is combined with a positive image of the company in the market. "Cold" calls, i.e. contact by phone with the offer of their goods and services are also a method based on the key role of the brokerage department.

A costly investment project needs to be assessed in terms of the effectiveness of investing money. For complex technology and long-term investment projects, it is more expedient to use a systematic approach and formalized methods of economic evaluation of the expected return on investment. This was discovered already in the second half of the last century by engineers designing a completely new technology and technology for the time: power lines, bridges and railways [7]. They needed to estimate the cost recovery for additional railway branches or additional copper consumption for wires with better conductivity and lower thermal losses.

Within the engineering economics, new directions have appeared already in the 20th century, with a large share of mathematical and statistical calculations (operation research, optimization of technical solutions in conditions of uncertainty), and more applied technical and economic ones (the method of reduced costs, functional and cost analysis). Based on these methods, as well as the development of the theory of financial management and the analysis of cash flows, the methodology of commercial project appraisal develops by the mid of 1970 s.

In the USSR, at the end of the 20-ies in the metallurgy and power engineering and other branches of the developing heavy industry, the methodology of recoupment as a method of reduced costs begins to be used for a formalized evaluation of projects. Since the mid of $30 \mathrm{~s}$, the share of systematized estimates has fallen and is almost completely replaced by an intuitive approach (discretionary decisions). Among the systematized assessments of numerous at that time projects, the analysis of only the cost of production of future production becomes the most common (without taking into account the initial capital expenditures investments). Practical decision-making on the criterion of the minimum cost price becomes a prerequisite for the creation of a new methodology of functional and cost analysis in the 40 s of the 20 th century.

It should be noted that the method of reduced costs is still used by some developers in Russia to evaluate the project and usually leads to unsuccessful attraction of investors. However, this method has in the current situation a somewhat different and rather narrow scope. It is effective for comparing various technological alternatives within a single enterprise, while investing own funds in the development and re-equipment of existing production with new equipment.

The method of recouping costs in a market economy was transformed by the mid of 1970 s (based on the use of new methods of financial management) in the methodology of commercial project evaluation.

The variety of methods used by various companies and state bodies necessitated their systematization, which was what the intergovernmental organization at the United Nations 
did. The so-called UNIDO methodology was created, on which the most widely used international standards for evaluating investment projects and business planning are based now.

The use of formalized methods of economic evaluation, even with significant uncertainty of projects, allows decision-makers to better understand the risk factors in investment alternatives, to obtain information for a more objective choice of economical options [8]. The application of systematic methods of economic evaluation makes it possible to exclude strong-willed decisions and demonstration of executives extravagance as a basis for choosing investment decisions [9-10].

However, when choosing the method of commercial evaluation of real estate construction projects, it is necessary to dwell on the general criteria for making decisions by investors whose choice is currently debatable, namely:

- Completeness and reliability of the initial information on the project (for example, in addition to data on planned costs and revenues, ownership rights of all project participants, public opinion and many other, often non-financial and non-economic information);

- Reliability and credibility of prospective project managers and developers, assessment of the possibility of solving financial and organizational issues, their financial and technological viability;

- Reliability and credibility of analysts and experts in the commercial evaluation of the project.

\section{Conclusion}

As a result of the analysis of the development of construction and real estate markets in St. Petersburg, the following conclusions can be drawn:

1. The most attractive target is the target segment of industrial construction, it is the most profitable and high-tech segment in terms of the use of global and innovative technical solutions, demanding the appropriate technical specialists in the company. Also, the entry barrier for competitors is the availability of the necessary documents confirming their qualifications and financial stability, preventing them from starting work with minimal financing or by confirming guarantees, by pledging assets. All these factors do not allow medium and small companies to enter this segment, leaving only strong players who lead the consolidation and are struggling to increase the share of the target segment in the industry, not by lowering the price, but by offering additional value to the consumer.

2 . The segment of construction of commercial real estate is the most competitive segment of the construction industry in the field of engineering; it contains most of the competing companies that do not have a clearly pronounced competitive advantage in relation to each other. Moreover, the consumer in this segment is not ready to pay for the advantage and the price of services that generates price wars comes to the fore.

3. The segment of residential housing construction is the least profitable segment due to the primitiveness of engineering systems. Intermediate consumers of this market (general contractors) follow the path of direct integration, creating within their structure assembly units that perform these works for the end user. Through the effect of scale, general contractors create serious competition for engineering companies, reducing profitability to a minimum or zero in this segment. The main criterion of the consumer in this segment is the price. Authors should use the forms shown in Table 3 in the final reference list. 


\section{References}

1. D.G. Proverbs, Holt, G.D., Olomolaiye, P.O. International Journal of Project Management. Vol. 17, Issue 3, pp. 195-204 (1999)

2. V. Ireland, Construction Management and Economics, Vol. 3, Issue 1, pp. 59-87 (1985)

3. R. Sacks, Journal of Construction Engineering and Management. Vol. 133, Issue 5, pp. 374-384 (2007)

4. Y.-M. Cheng, International Journal of Project Management. Vol. 32, Issue 5, pp. 850860 (2014)

5. R. Turkington, High-rise housing in Europe. Current trends and future prospects. DUP Science. Delft University Press. The Netherlands.

6. G. Finkel, The economics of the construction industry. Routledge. (Taylor and Francis Group. New York. USA, 2015)

7. I. Ilin, et al, Model of asset portfolio improvement in structured investment products. Life Science Journal, Vol. 11, Issue 11, pp. 265-269 (2014)

8. L.V. Nikolova, D.G. Rodionov, N.V. Afanasyeva, European Research Studies Journal, Vol. 20, Issue 2, pp. 396-410 (2017)

9. V.V. Glukhov, I.V. Ilin, Lecture Notes in Computer Science, Vol. 8638 LNCS, pp. 509518 (2014)

10. I.V. Ilin, A.B. Anisiforov, WSEAS Transactions on Business and Economics, Vol. 11, pp. 757-764 (2014) 